\title{
The Role of Metacognitive Strategies on Persian Students’ Vocabulary Learning
}

\author{
Khorami Mohammad \\ Payam Noor University of \\ Bojnourd, Bojnourd, Iran
}

\author{
Fathvalizadeh Ali \\ Educational Center of \\ Tehran, Tehran, Iran
}

\author{
Mohammadniya Yaser \\ Medical Science \\ University of North \\ Khorasan, North Khorasan, \\ Iran
}

\author{
Seadatee-Shamir \\ Aboutaleb \\ University of Bojnourd, \\ Bojnourd, Iran
}

\begin{abstract}
Research reveals that just some of L2 (second language) strategy training has been successful and effective for vocabulary learning. The purpose of the present study was investigated the effect of metacognitive strategy training through the use of explicit strategy instruction on the development of lexical knowledge of EFL (English as a second language learning) students. Two groups of EFL Irainian language learners (60 participants) at intermediate language proficiency level which were selected by random sampling were assigned to control and experimental groups. Only the experimental group received metacognitive strategy training during the course of the semester. ANCOVA (Analysis of covariance) was employed for data analysis. Result showed explicit metacognitive strategy training has a significant positive effect on the vocabulary learning of EFL students.
\end{abstract}

Keywords: metacognitive strategies, Persian students, vocabulary learning

\section{Introduction}

Metacognition involves "active monitoring and consequent regulation and orchestration of cognitive process to achieve cognitive goals" (Flavell, 1976). Flavell and Wellman (1977), and Flavell (1979) included interpretation of ongoing experience, or simply making judgments about what one knows or does not know to accomplish a task, as other features of metacognition. Along with the notions of active and conscious monitoring, regulation, and orchestration of thought process, Flavell (1976) believed through repeated use of metacognition, it might in time become automatized.

Research on vocabulary learning strategies has been done in several aspects: (1) research on several languages (most of them in an EFL (English as second language learning) setting); (2) research on comparing strategy use at several proficiency levels; and (3) research on cognitive and metacognitive strategies. But it should be noted that few studies were done in an EFL setting and the size of the sample was small.

It has been claimed that successful language learners have their own "special ways of doing it". Stern (1975) and Rubin (1975) were probably among the first researchers who brought up the idea of successful language learners. The idea can probably help us with both understanding more about the nature of language

Khorami Mohammad, M.A., lecturer, Payam Noor University of Bojnourd.

Fathvalizadeh Ali, M.A., Educational Center of Tehran.

Mohammadniya Yaser, M.A., Medical Science University of North Khorasan.

Seadatee-Shamir Aboutaleb, assistant professor of educational psychology, University of Bojnourd. 
learning and also to facilitate the language learning process for others. Since this premise, most of the research in the area of language learning strategies has focused on the identification, description, and classification of useful learning strategies. The research has been descriptive with the aim to elicit the useful strategies applied by successful language learners assuming that it could help other learners to become more successful.

Rubin (1975) suggested that good L2 (second language) learners are willing and accurate guessers; have a strong drive to communicate; are often uninhibited; are willing to make mistakes; focus on form by looking for patterns and analyzing; take advantage of all practice opportunities; monitor their speech as well as that of others; and pay attention to meaning. Naiman, Frohlich, and Todesco (1975) made a list of strategies used by successful L2 learners, adding that they learn to think in the language and address the affective aspects of language acquisition as well.

In the 1980s and early 1990s, research mainly focused on categorizing the strategies found in the studies of the previous decade. As a result, several taxonomies were proposed to classify them, including classifications of language learning strategies in general and language sub-skills strategies in particular. O'Malley and Chamot (1990), for instance, had divided the strategies into three main branches: cognitive, metacognitive, and socio-affective, each of which includes lots of sub-strategies such as rehearsal, organization, summarizing, deducing, and imagery. On the other hand, Oxford (1990a) has proposed a more comprehensive model in which six categories, classified into two groups of direct and indirect existences. The direct strategies include memory, cognitive, and compensation while indirect strategies include metacognitive, affective, and social.

Among learning strategies, metacognitive strategies are considered as the most essential ones in developing learners' skills (Anderson, 1991) and it was emphasized by O’Malley et al. (1985) that learners without metacognitive approaches have no direction or ability to monitor their progress, accomplishments, and future learning directions. On the other hand, learners who have developed their metacognitive awareness are likely to become more autonomous language learners (Hauck, 2005). Similarly, Chamot (2005) pointed out that less successful language learners do not have the metacognitive knowledge needed to select appropriate strategies. Goh (2002) emphasized the importance of metacognitive strategies by arguing that learners' metacognitive awareness is related to effective learning in all learning contexts. Goh and Yusnita (2006) drew attention to the specific context of L2 listening and claimed that strategies have a direct and positive influence on vocabulary learning. Yang (2009) also indicated that one of the distinctive features differentiating successful vocabulary learner from unsuccessful ones is their use of metacognitive strategies and he supported the idea that teaching the role of metacognition in L2 listening helps listeners to approach the listening task more effectively. As Luo-Xiang (2005) concluded, more discussion is needed to increase learners' metacognitive awareness in vocabulary learning. In the light of this research, the aim of this study is to research the effect of metacognitive strategy training and its effect on vocabulary learning performance.

In this study, we hold that metacognition contains two concepts: metacognitive knowledge and metacognitive strategies. Metacognitive knowledge covers knowledge about person, knowledge about task, and knowledge about strategy. Metacognitive strategies refer to an ability to manage and regulate the use of suitable learning strategies for different tasks, including such strategies as planning, monitoring, or evaluating. This indicates that a language learner is able to evaluate the learning situation, to make plans, to choose suitable skills, to sequence them, to coordinate them, to check their effectiveness, and to change the plan when necessary. Metacognitive knowledge and metacognitive strategies form a reciprocal relationship. Metacognitive 
knowledge is a necessary step in learning to manage learning and metacognitive strategies are the actual deployment of metacognitive knowledge (Yang, 2009).

It has been suggested that learning strategy instruction may help learners in three ways: Firstly, learning strategies instruction can help students to become better learners; Secondly, skill in using learning strategies assists them in becoming independent and confident learners; And finally, they become more motivated as they begin to understand the relationship between their use of strategies and success in learning languages (Chamot \& Kupper, 1989; Chamot \& O’Malley, 1994).

Finally, as it has been suggested by some researchers including, Brown (1994), Chamot et al. (1999), Chamot and Coady (1997), one of the areas that teachers could help their students in relation to learning strategies could be to familiarize them with different lexical learning strategies, which would lead to more autonomy in students. Moreover, most of the studies in learning strategies have concentrated on identification, description, and classification of learning strategies used by language learners. As a result, more attention should be paid to find whether strategies used by successful students can be taught to unsuccessful students, and if so, what instructional approaches of teachers should use to teach the strategies. To achieve the purpose of the study of the following research question was proposed: "Does the metacognitive strategies instruction significantly increase the lexical knowledge of Iranian EFL students?”

\section{Methodology}

\section{Subjects}

The participants of the study were 60: male (30) and female (30), Iranian EFL students taking part in an intensive course of English in Bojnourd language institute aged 18 to 33. The average age of the subjects was 26. They were studying English to enroll later in either English business classes or information technology classes. They had passed headway elementary achievement test with at least $65 \%$ of the whole score. They were assigned to two classes and considered at pre-intermediate level of language proficiency. One of the classes was randomly selected as the control group and the other class as experimental group.

Two instruments were used in this study. The first one was Nelson Language Proficiency test which was used as a standardized measure to check the homogeneity of subjects in terms of language proficiency and also to be used as a standardized measure to check the reliability and validity of our vocabulary test. The second one was a 40-item multiple-choice test of vocabulary, which was developed by the researchers. The vocabulary items in the test were mainly selected from the new lexical items taught and exposed to during the course.

\section{Procedure}

Both experimental and control groups enrolled in an English course which lasted for 10 weeks (four hours a day, three days a week). The textbook used for this course was headway pre-intermediate. The authors have emphasized the role of lexical knowledge in learning the English language and have put some sections on vocabulary learning strategies in the book. One of the researchers taught both classes.

Both groups received the usual training based on the procedures suggested in the headway teacher's book. The vocabulary strategies which were covered in the book were summarized and taught in the first session for both groups. The instruction and use of vocabulary learning strategies continued throughout the course for both groups of subjects. It is believed that metacognitive strategies are responsible for controlling other strategies and as a result they have their best effects if students are aware of other strategies that are available to them at the beginning of the course (O’Malley \& Chamot, 1990, p. 230). 
Only the experimental group received explicit instruction on metacognitive strategies beginning from the second day of the course. The training was based on CALLA (cognitive academic language learning approach) model of teaching-learning strategy which includes five steps: preparation, presentation, practice, evaluation, and expansion. At the end of the course, both the control group and the experimental group were given the vocabulary achievement test and the results of the tests were compared to find the effects of the training.

\section{Data Analysis}

ANCOVA (Analysis of covariance) indicated that there was no significant difference $(F=1.18$, Sig. $=$ $0.662, a<0.05$ ) between the control and experimental group in pretest. It means that, the two groups were homogenous in terms of lexical knowledge of the new items of the course book at the beginning of the course. Also result shows that there was a significant difference $(F=4.69$, Sig. $=0.004, a<0.05$ ) between the control and experimental group in posttest. Higher mean score of experimental group (33.50) in comparison with control group (26.86) shows that they outperformed control group. So, it means that, metacognitive strategies had a significant and full meaning effect on vocabulary learning in Iranian EFL students. The result is presented in Table 1.

Table 1

Descriptive Results and Analysis of Covariance

\begin{tabular}{|c|c|c|c|c|c|c|c|c|c|}
\hline & $M$ & & $S D$ & & ss & $d f$ & Ms & $F$ & Sig. \\
\hline Source pretest & $\begin{array}{l}\text { C } \\
26 / 08\end{array}$ & $\begin{array}{l}\text { e } \\
26 / 06\end{array}$ & $\begin{array}{l}\text { c } \\
6 / 66\end{array}$ & $\begin{array}{l}\text { e } \\
6 / 62\end{array}$ & $35 / 01$ & 1 & $35 / 01$ & $1 / 07$ & $0 / 662$ \\
\hline Main effect & 26/89 & $33 / 50$ & $6 / 72$ & $5 / 46$ & $7 / 01$ & 1 & $7 / 01$ & $4 / 69$ & /004 \\
\hline
\end{tabular}

Notes. $R$-squared $=0.257$ (adjusted $R$-squared $=0.171$ ); $\mathrm{c}=$ Control group; e $=$ Experimental group; $M=$ Mean; $S D=$ Standard deviation; $s s=$ Sum of squares; $d f=$ Degree of freedom; $M s=$ Sum of squares; $F=F$-test; Sig. $=$ Significance.

\section{Conclusion}

The main objective of this study was to explore the effect of metacognitive strategy training on students' vocabulary learning. Although this study sheds some light on the usefulness of metacognitive strategy training in vocabulary learning classes, the findings cannot be generalized to all EFL contexts in Iran as the number of participants, of such studies is low. Therefore, further studies should explore the effectiveness of metacognitive strategy training with higher number of students and allocate a longer period of time than only 10 weeks that is the time spent on the training for the current study.

In addition, more comprehensive research on different variables such as participants' cultural background and proficiency levels of English is necessary. Different strategy training models and test types should also be used in future research studies to come to the sound conclusion that metacognitive strategy training does actually matter as far as L2 vocabulary learning is concerned. More research is needed on a possible cause and effective relationship between some other learning strategies (e.g., cognitive and socioaffective) and vocabulary performance as well. As this study is only about the influence of metacognitive strategy training on L2 vocabulary learning, more research should be carried out to investigate the effect of certain metacognitive strategies on different language skills or sub-skills performance in order to claim that metacognitive strategy training is effective in learning English in general. English teachers in different local settings should take such studies as their starting point and engage in classroom research in order to come to more sound conclusions 
about the effectiveness of strategy training on students' performance in their classrooms. By reflecting upon their teaching experiences, they can even develop their own strategy training models suitable for their local context.

Finally, the idea of self-regulation and empowerment with strategic instruction will possibly prove more effective in certain contexts. Where learners of EFL have been educated in a more teacher-centered, top-down curriculum rather than one that promotes learners' autonomy and independence, strategy instruction could prove most effective.

\section{References}

Altman, R. (1997). Oral production of vocabulary: A case study. In J. Coady, \& T. Huckin (Eds.), Second language vocabulary acquisition (pp. 69-97). Cambridge: Cambridge University Press.

Anderson, J. R. (1985). Cognitive psychology and its implications (2nd ed.). San Francisco: Freeman.

Anderson, N. J. (2002a). The role of metacognition in second language teaching and learning. ERIC Digest. Education Resources Information Center.

Anderson, N. J. (2002b). The role of metacognition in second language teaching and learning. Oxford: Oxford University Press.

Anderson, N. J. (2002b). Using telescopes, microscopes, and kaleidoscopes to put metacongnition into perspective. TESOL Matters, 12(4), 2002.

Bachman, L. F., \& Palmer, A. S. (1996). Language testing in practice. Oxford: Oxford University Press.

Brown, H. D. (1994). Principles of language learning and teaching (3rd ed.). Englewood Cliffs: Prentice Hall.

Brown, T. S., \& Perry, F. L. (1991). A comparison of three learning strategies for ESL vocabulary acquisition. TESOL Quarterly, 25, 655-670.

Carrell, P. L., Pharis, B. G., \& Liberto, J. C. (1989). Metacognitive strategy training for ESL reading. TESOL Quarterly, 23, 647-678.

Chamot, A. U. (2005). Language learning strategy instruction: Current issues and research. Annual Review of Applied Linguistics 25, 112-130.

Chamot, A. U., \& O’Malley, J. M. (1994). Language learner and learning strategies. In N. C. Ellis (Ed.), Implicit and explicit learning of languages (pp. 371-392). London: Academic.

Coady, J. (1997). L2 vocabulary acquisition through extensive reading. In J. Coady, \& T. Huckin (Eds.), Second language vocabulary acquisition (pp. 225-237). Cambridge: Cambridge University Press.

Cohen, A. D. (2000). Strategies in learning and using a second language. Foreign Education, 60(4), 293-306.

Cottrell, S. (1999). The study skills handbook. London: Macmillan Press.

Ehrman, M., \&. Oxford, R. (1990). Adult language learning styles and strategies in an intensive training setting. Modern Language Journal, 74, 311-327.

Ellis, R. (1985). Sources of variability in interlanguage. Applied Linguistics, 6, 118-131.

Ellis, R. (1995). Modified oral input and the acquisition of word meaning. Applied Linguistics, 16, 409-441.

Flavell, J. H. (1976). Metacognitive aspects of problem solving. In L. B. Resnick (Ed.), The nature of intelligence. Hillsdale, N. J.: Erlbaum.

Flavell, J. H. (1979). Metacognition and cognitive monitoring. American Psychologist, 34, 906-911.

Flavell, J. H., \& Wellman, H. M. (1977). Metamemory. In R. V. Kail, \& J. W. Hagen (Eds.), Perspectives on the development of memory and cognition. Hillsdale, N. J.: Erlbaum. Foreign Language Annals, 29(3), 331-342.

Kern, R. G. (1989). Second language reading strategy instruction: Its effects on comprehension and word inference ability. Modern Language Journal, 73, 135-149.

Kluwe, R. (1982). Cognitive knowledge and executive control: Metacognition. In D. R. Griffin (Ed.). Animal mind-human mind (pp. 201-24). New York: Springer-Verlag.

Luo-Xian, S. (2005). Metacognitive awareness and second language listeners. Media in Foreign Language Instruction, 6, 55-56.

Nunan, D. (1991). Language learning methodology. London: Prentice Hall.

O'Malley, J. M., \& Chamot, A. U. (1990). Learning strategies in second language acquisition. Cambridge: Cambridge University Press. 
Oxford, R. L. (1989). Use of language learning strategies: A synthesis of studies with process of L2 listening. Canadian Modern Language Review, 59, 425-440.

Parry, K. (1997). Vocabulary and comprehension: Two portraits. In J. Coady, \& T. Huckin (Eds.), Second language vocabulary acquisition (pp. 55-68). Cambridge: Cambridge University Press.

Ridley, D. S., Schutz, P. A., Glanz, R. S., \& Weinstein, C. E. (1992). The interactive influence of metacognitive awareness and goal-setting. Journal of Experimental Education, 60, 293-306.

Rubin, J. (1975). What the “good language learner” can teach us. TESOL Quarterly, 9, 41-51.

Sanaoui, R. (1995). Adult learners’ approaches to learning vocabulary in second language. The Modern Language Journal, 79, $15-28$.

Seferoglu, G., \& Uzakgören, S. (2004). Equipping learners with listening strategies in English. Faculty of Education Journal, 27, 223-231.

Stern, H. H. (1975). What can we learn from the good language learner? Canadian Modern Language Review, 31, 304-318.

Thompson, I., \& Rubin, J. (1996). Can strategy instruction improve listening comprehension? Foreign Language Annals, 29(3), 331-342.

Vandergrift, L. (1997). The comprehension strategies of second language (French) listeners. Modern Language Journal, 81(4), 12-23.

Wenden, A. L. (1987). Incorporating learner training in the classroom. In A. L. Wenden, \& J. Rubin (Eds.), Learner strategies in language learning (pp. 31-42). Englewood Cliffs, N. J.: Prentice Hall.

Yang, C. (2009). A study of metacognitive strategies employed by English listeners. International Education Studies, 2(4), 213-223. 